Peter Selz 
This page intentionally left blank 


\section{Peter Selz}

SK E T C H E S OF A LIFE I N A R T

PA U L J . K A R L S T R O M

w гтн Ann Heath Karlstrom

甲

U N I VERSITY OF CALIFORNIA PRESS Berkeley Los Angeles London 
University of California Press, one of the most distinguished university presses in the United States, enriches lives around the world by advancing scholarship in the humanities, social sciences, and natural sciences. Its activities are supported by the UC Press Foundation and by philanthropic contributions from individuals and institutions.

For more information, visit www.ucpress.edu.

University of California Press

Berkeley and Los Angeles, California

University of California Press, Ltd.

London, England

(C) 2012 by The Regents of the University of California

Every effort has been made to identify the rightful copyright holders of material not specifically commissioned for use in this publication and to secure permission, where applicable, for reuse of all such material. Credit, if and as available, has been provided for all borrowed material either on-page, on the copyright page, or in an acknowledgment section of the book. Errors or omissions in credit citations or failure to obtain permission if required by copyright law have been either unavoidable or unintentional. The author and publisher welcome any information that would allow them to correct future reprints.

Library of Congress Cataloging-in-Publication Data

Karlstrom, Paul J.

Peter Selz : sketches of a life in art / Paul J. Karlstrom with Ann Heath Karlstrom. —ist ed.

p. $\mathrm{cm}$.

Includes bibliographical references and index.

ISBN 978-0-520-26935-4 (cloth : alk. paper)

1. Selz, Peter Howard, 1919- 2. Art historians-United StatesBiography. 3. Art critics-United States-Biography. 4. Art museum curators-United States-Biography. I. Selz, Peter Howard, 1919II. Karlstrom, Ann Heath. III. Title.

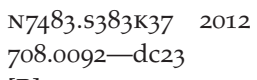

[B]

2011022766

Manufactured in the United States of America

$\begin{array}{llllllllll}21 & 20 & 19 & 18 & 17 & 16 & 15 & 14 & 13 & 12\end{array}$

$\begin{array}{llllllllll}10 & 9 & 8 & 7 & 6 & 5 & 4 & 3 & 2 & 1\end{array}$

In keeping with a commitment to support environmentally responsible and sustainable printing practices, UC Press has printed this book on Rolland Enviro10o, a 100\% post-consumer fiber paper that is FSC certified, deinked, processed chlorine-free, and manufactured with renewable biogas energy. It is acid-free and EcoLogo certified. 